\title{
Effect of Increasing Amounts of Ammonium Nitrogen Induced by Consecutive Mixture of Poultry Manure and Cattle Slurry on the Microbial Community during Thermophilic Anaerobic Digestion
}

\author{
Khulud Alsouleman ${ }^{1,2 *}$ \\ ${ }^{1}$ Department Bioengineering, Leibniz Institute for Agricultural Engineering and Bioeconomy (ATB), Potsdam, Germany \\ ${ }^{2}$ Faculty of Agricultural Sciences, Georg-August-Universität Göttingen, Göttingen, Germany
}

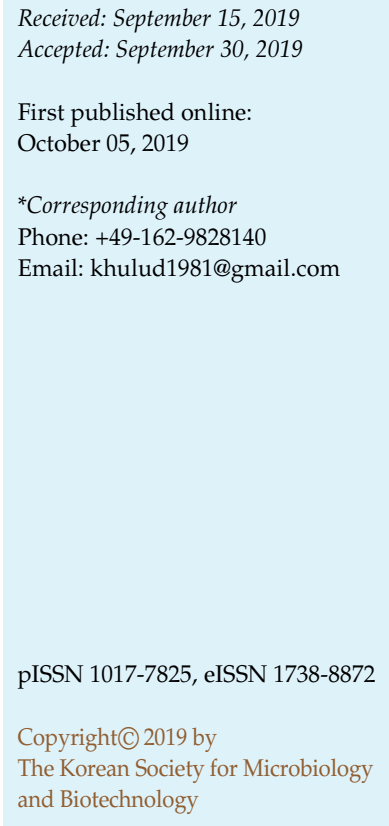

Thermophilic anaerobic digestion (TAD) is characterized by higher biogas production rates as a result of assumedly faster microbial metabolic conversion rates compared to mesophilic AD. It was hypothesized that the thermophilic microbiome with its lower diversity than the mesophilic one is more susceptible to disturbances introduced by alterations in the operating factors, as an example, the supply of nitrogen-rich feedstock such as poultry manure (PM). Laboratory scaled TAD experiments using cattle slurry and increasing amounts of PM were carried out to investigate the (in-) stability of the process performance caused by the accumulation of ammonium and ammonia with special emphasis on the microbial community structure and its dynamic variation. The results revealed that the moderate PM addition, i.e., $25 \%$ (vol/vol based on volatile substances) PM, resulted in a reorganization of the microbial community structure which was still working sufficiently. With 50\% PM application, the microbial community was further stepwise re-organized and was able to compensate for the high cytotoxic ammonia contents only for a short time resulting in consequent process disturbance and final process failure. This study demonstrated the ability of the acclimated thermophilic microbial community to tolerate a certain amount of nitrogen-rich substrate.

Keywords: Ammonia inhibition, microbiome, process disturbance, biogas

\section{Introduction}

Reducing greenhouse gas emissions resulting from open storage and uncontrolled spreading of animal slurries and manures is a major challenge faced by the agricultural sector [1]. One of the most important and commonly applied technologies to achieve this goal is the bioconversion of animal wastes into energy-rich biogas by anaerobic digestion (AD) $[2,3]$.

The thermophilic AD $\left(\mathrm{TAD}, 50-60^{\circ} \mathrm{C}\right)$ has generally higher metabolic rates and hence higher overall process efficiency than mesophilic $\mathrm{AD}$ performed at $37^{\circ} \mathrm{C}$ [4-7]. On the other hand, TAD is very sensitive to changes in operating factors such as total solids (TS), mixing rate, organic loading rate (OLR), pH, volatile fatty acid (VFA) content, and total ammonium nitrogen content (TAN) which in turn reduce the process stability [8-11].

Due to the cytotoxic effects of ammonia $\left(\mathrm{NH}_{3}\right)$, resulting from deprotonation of ammonium $\left(\mathrm{NH}_{4}^{+}\right)$, many efforts have been previously made to determine the TAN thresholds in mesophilic and thermophilic AD processes which ranged between 1.8 and $5.0 \mathrm{~g} \mathrm{NH}_{4}{ }^{+}-\mathrm{N} / \mathrm{L}$. These inhibition thresholds varied widely due to the direct or indirect effect of many other factors such as the substrate composition, the initial nitrogen concentrations, the temperature, the $\mathrm{pH}$, the OLR, the acclimation period, and the acclimation of the inoculum [12-20].

The efficiency and stability of the AD process are entirely dependent on the concerted and syntrophic activity of the involved microorganisms. Several studies investigated basically the effect of increasing TAN on the thermophilic microbial community structure [11, 21-25]. For example, 
Hao et al. [21] showed in batch thermophilic acetate fed experiments at two TAN (low, i.e., $0.26 \mathrm{~g} / 1$, and high, i.e., $7.00 \mathrm{~g} / 1)$ - that the microbial communities were similar for both TAN conditions. While in a previous work the syntrophic acetate oxidation coupled with hydrogenotrophic methanogenesis was shown as the dominant pathway in both mesophilic and thermophilic full-scale anaerobic digesters with high ammonia levels (2.8-4.57 $\left.\mathrm{g} \mathrm{NH}_{4}{ }^{+}-\mathrm{N} / \mathrm{L}\right)$, whereas the acetoclastic methanogenic pathway dominated at low ammonia content $\left(<1.21 \mathrm{~g} \mathrm{NH}_{4}{ }^{+} \mathrm{N} / \mathrm{L}\right)$ [22]. Other studies showed that the mesophilic microbial community shifted significantly as members belonging to the Bacteroidetes and Methanosaeta were gradually disappeared with elevated TAN and hence elevated $\mathrm{NH}_{3}$ contents $[20,26,27]$.

However, with main focus on the reactor performance and the microbial community structure of the TAD of nitrogen-rich substrate, only a few is known about the relationship between TAD microbial community shifts and performance variation resp. disturbances due to the accumulation of TAN.

We hypothesized that the potential impact of the stepwise increase of the TAN, as a consequence of the application of nitrogen-rich fermentation substrates, and hence the consequent prevalent operational process conditions will lead to more serious disturbances in the TAD process compared to mesophilic ones as previously published by Alsouleman et al. [20]. So that, this study focused mainly on the (in-) stability of the long-term TAD process in terms of biogas and methane yield, VFA content and accumulation of TAN as a response to the environmental perturbations arising from increasing amounts of poultry manure (PM). Also the response of the thermophilic microbial community was determined by $16 \mathrm{Sr}$ RNA gene targeted terminal restriction fragment length polymorphism (TRFLP) fingerprinting which allows the direct screening and comparison of microbial communities' dynamics in different samples [28-36]. Subsequent determination of respective nucleotide sequences enables the identification of representatives for the most abundant taxa [37-39].

\section{Materials and Methods}

\section{Experimental Setup and Biogas Reactor Operation}

Two thermophilic $\left(55^{\circ} \mathrm{C}\right)$ continuously resp. completely stirred tank reactors (CSTRs) with a working volume of $8 \mathrm{~L}$ were operated in parallel for (385 days), allowing the adaptation of the microbial community to the apparent process conditions. The start-up of the CSTRs was conducted according to [40]. To ensure a high diversity of a well-performing starter community, both reactors were initiated with anaerobic inoculum from previous experimental reactors which were fed with cattle and pig slurry as well as maize silage. This inoculum was diluted 1:2 with tap water before inoculation. During the first 75 days, both reactors were fed with CS starting with an organic loading rate (OLR) of $0.5 \mathrm{~g}_{\mathrm{vs}} / 1 / \mathrm{d}$ and gradually increased (using $0.5 \mathrm{~g}_{\mathrm{vs}} / 1 / \mathrm{d}$ steps) until the final OLR of $3.0 \mathrm{~g}_{\mathrm{vs}} / 1 / \mathrm{d}$ was achieved. Afterwards, the OLR was maintained at $3.0 \mathrm{~g}_{\mathrm{vs}} / 1 / \mathrm{d}$ for the further 65 days.

To avoid process inhibition through a lack of micronutrient, $10 \mu \mathrm{l}$ of the trace element solution DSMZ 144 was added per $\mathrm{g}$ volatile solids (VS) (German collection of microorganisms and cell cultures, Germany) as recommended by [41]. Both reactors were operated at stable conditions indicated by $\mathrm{pH}, \mathrm{VFA}$ as well as biogas yield and methane content.

The experimental CSTR (= ER) was fed with an increasing amount (based on VS) of PM as followed whereby the OLR was kept constantly at $3.0 \mathrm{~g}_{\mathrm{vS}} / \mathrm{l} / \mathrm{d}$ : first experimental period (= EP1) with $75 \%$ CS and 25\% PM for 176 days and hydraulic retention time (HRT) of 26 days; second experimental period (= EP2) with $50 \%$ CS and 50\% PM for 165 days and HRT of 39 days. Over the entire $\mathrm{EP}$, the control reactor (CR) was operated with CS as sole substrate with a constant OLR of $3.0 \mathrm{~g}_{\mathrm{vS}} / \mathrm{l} / \mathrm{d}$ equal to the OLR of the ER.

Biogas production was monitored daily using a drum-type gas meter (Meter TG 05, Ritter Apparatebau, Germany). The biogas composition was analysed three times per week using the gas analyser SSM 6000 (Pronova Analysentechnik, Germany).

\section{Chemical Characterization of the Used Feedstocks and Digestate Samples}

The used feedstocks as well as the digestate samples (sampling twice a week), were analysed as follows: Total solids (TS), volatile solids (VS), total Kjeldahl nitrogen (TKN), the $\mathrm{NH}_{4}{ }^{+}$-N content, the amounts of VFA in terms of acetate, propionate, iso- and nbutyrate, iso- and n-valerate, and capronate were analysed according to [42]. The $\mathrm{pH}$-value was measured three times a week using $\mathrm{pH} /$ cond $340 \mathrm{i}$ with the $\mathrm{pH}$-Electrode SenTix41 (WTW, Germany).

The free ammonia $\left(\mathrm{NH}_{3}\right)$ content was calculated based on the $\mathrm{NH}_{4}{ }^{+}-\mathrm{N}$ content, the $\mathrm{pH}$-value and the reactor temperature using the formula previously described by Hansen [17].

\section{Microbial Community Analysis}

To investigate the process microbiology, samples were taken from the ER at following process-relevant time points; day 81, and 162 , i.e., the beginning and the end of EP1; day 199, i.e., the beginning of the EP2: day 250, i.e., the beginning of short-termed stable biogas yield period; day 300, i.e., the beginning of the biogas yield decrease period; day 340, i.e., the end of EP2. From the CR, samples were analysed for days 81 and 340, i.e., the beginning and the end of ER, as the CR showed an almost stable anaerobic digestion process during the whole ER as indicated by VFA content, biogas yield, and methane content. From two sub- 
samples of each sample (i.e., technical replicates), the microbial genomic DNA was extracted using the FastDNA SPIN Kit for soil (MP Biomedicals, Germany) according to the manufacturer's guidelines.

To characterize the microbial community structure, terminal restriction fragment length polymorphism (TRFLP) analysis targeting the bacterial or the archaeal 16Sr RNA gene was applied as described in [23].

16Sr RNA gene sequence analysis was conducted as described before [23]. The obtained sequences were processed, grouped into operational taxonomic units (OTUs) and virtually cut according to [43] using the software package BioNumerics 7.6 (Applied Maths, Belgium).

All sequences obtained in this study have been deposited in the European Molecular Biology Laboratory (EMBL) database under accession numbers LT718731 - LT718850 (Bacteria) and LT718710 LT718730 (Archaea).

\section{Statistical and Ecological Analysis}

Correlation coefficients among and between the operational and microbiological parameters, an indicator species analysis (ISA) [44], a non-metric multidimensional scaling (NMS) [45, 46], Gini coefficients $[47,48]$ in addition to Shannon [49] and Richness [47] diversity indices were estimated to show the correlation amongst and between the operational and microbiological parameters and to get more information about the microbial system ecology and the diversity of the microbial community. Detailed information on the whole materials and methods section is provided as supplemental material appendix 1 .

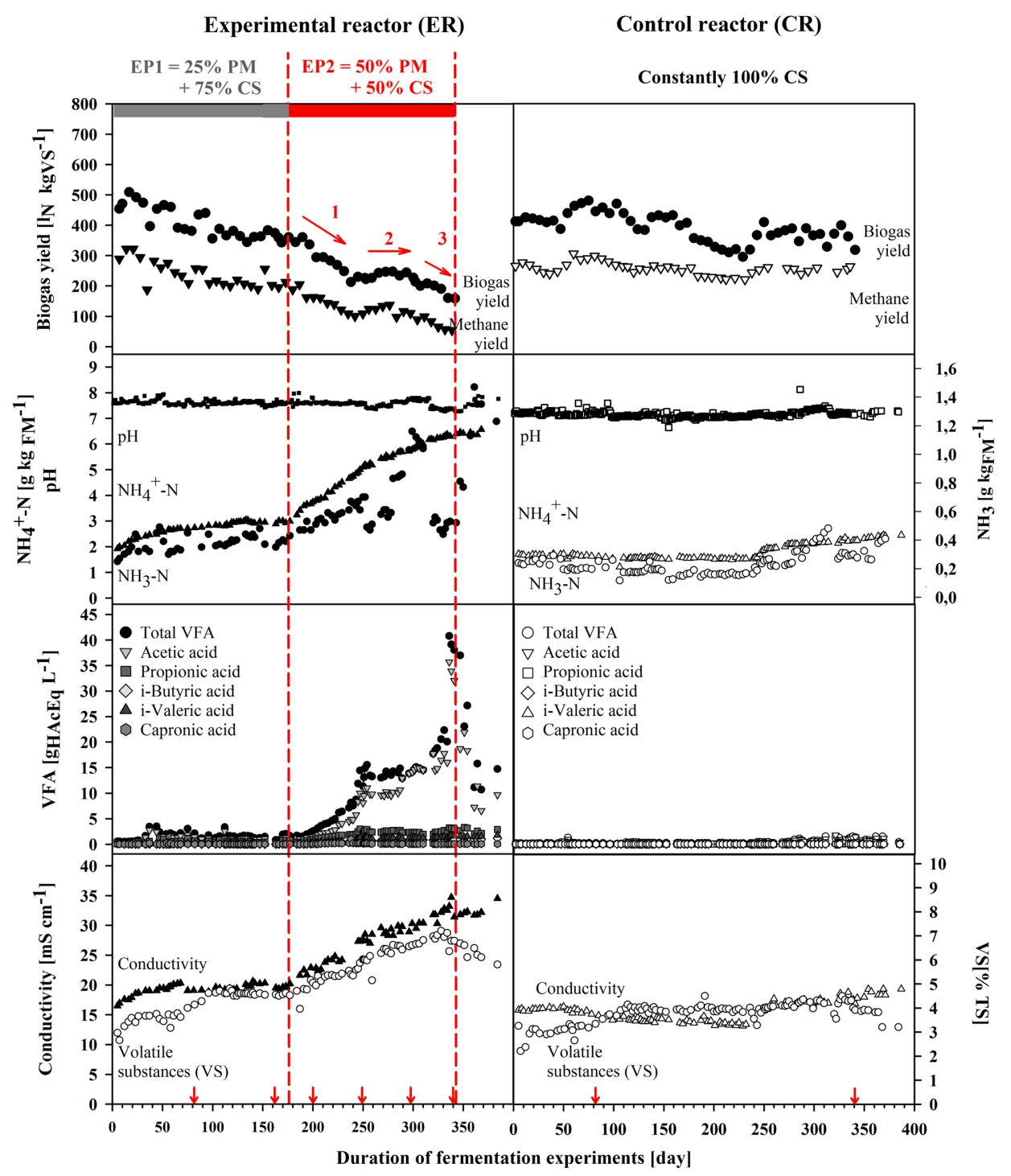

Fig. 1. Process performance parameters for the experimental (ER) and control reactor (CR) during experimental phases1 (EP1) and 2 (EP2).

The arrows on the $\mathrm{X}$-axis indicate sampling points for molecular analyses. The arrows 1, 2, 3 indicate three-stage process disturbance. 


\section{Results}

\section{Operation of CSTRs}

Changes in control and experimental TAD performance during the entire experimental period are shown in (Fig. 1). During both experimental periods (EP1 and EP2), the control reactor (CR) supplied exclusively with cattle slurry showed no significant changes in the produced biogas yield $\left(\mathrm{R} 2=0.27 ; p<3.7 \times 10^{-25}\right)$ (Fig. 1$)$. Thus, the almost stable chemical parameters in the $\mathrm{CR}$ indicated a more or less stable and metabolically active microbial biocoenosis.

In the experimental reactor (ER), as expected, the change of the feedstock composition during EP1 resulted in an increased TAN content up to $3.0 \mathrm{~g} \mathrm{NH}_{4}{ }^{+}-\mathrm{N} / \mathrm{kg}_{\mathrm{FM}}$ at the end of this experimental phase with a corresponding increase in $\mathrm{NH}_{3}$ content up to $0.4 \mathrm{~g} / \mathrm{kg}_{\mathrm{FM}}$ respectively (Fig. 1). The total VFA content which consisted mainly of acetic acid showed a minor increase in this experimental phase. The content of the other volatile fatty acids in terms of propionate, iso- and n-butyrate, iso- and n-valerate and capronate was found in minor amount and was more or less constant. The relative alteration of the VFA concentration (as acetic acid) during EP1 was $1.46 \mathrm{~g} / 1$ compared with $1.13 \mathrm{~g} / \mathrm{l}$ in control reactor. The $\mathrm{pH}$ value was almost stable with $7.62 \pm 0.09$ on average. However, the change of feedstock composition had no significant effect on the overall process performance indicated by a constant biogas content $\left(R^{2}=0.31 ; p=8.8 \times 10^{-16}\right)$.

In EP2, a gradual ongoing increase in the TAN was recorded and reached highest values of $6.3 \mathrm{~g} \mathrm{NH}_{4}{ }^{+} \mathrm{N} / \mathrm{kg}_{\mathrm{FM}}$ with a corresponding $\mathrm{NH}_{3}$ content of $0.5 \mathrm{~g} / \mathrm{kg}_{\mathrm{FM}}$ at the end of this experimental phase. No evident alteration in the $\mathrm{pH}$ value was recorded during the EP2 which recorded an averaged value of $7.56 \pm 0.14$. Also, a gradual increase in the VFA content was recorded, which reached up to $15.5 \mathrm{~g} / 1$ at day 253. Presumably the increased VFA content and also the increased TAN/ $\mathrm{NH}_{3}$ content led to a decrease in the biogas yield as well as in the methane content (Fig. 1, first phase showing process disturbance resp. microbiome inhibition). Afterwards (from day 254 to day 309), a gradual increase in the TAN and a constant and stable VFA content of approximately $14.0 \pm 0.7 \mathrm{~g} / 1$ were recorded. So that, a short-termed stable biogas yield- indicated by comparatively constant biogas yield of $235.1 \pm 44.57 \mathrm{~L}_{\mathrm{N}} / \mathrm{kg}_{\mathrm{vs}}$ over 55 days- was recorded indicating a stabilisation of the process performance and microbial activity (Fig. 1, second phase showing short-termed stable biogas yield). After that and with continuous applying of $50 \% \mathrm{PM}$, an ongoing accumulation of the VFA was recorded resulting in VFA content of $38.1 \mathrm{~g} / 1$ accompanied with a decreasing in the biogas yield to $158.8 \mathrm{~L}_{\mathrm{N}} / \mathrm{kg}_{\mathrm{vs}}$ with a methane content of $35.8 \%$ at the end of EP2. The previous conditions symbolized a critical resp. significant process disturbance (Fig. 1, third phase showing process disturbance resp. microbiome inhibition).

\section{Alteration of the Microbial Community Structure in the Response of TAN Increase}

The dynamic variation of the microbial community was investigated by the fingerprinting method TRFLP targeting either the bacterial or the archaeal 16SrRNA genes based on the samples ER-81, ER-162, ER-199, ER-250, ER-300, and ER-340 from the ER, and CR- 81 and CR-340 of the CR, followed by taxonomic profiling of the microbial community by $16 \mathrm{~S}$ rRNA gene nucleotide sequence analysis of the samples ER-81, ER-250, ER-340, and CR-81.

The Shannon and the Richness indices for microbial diversity were calculated and presented in (Table 1). Both

Table 1. Statistical parameters of bacterial and archaeal 16S RNA gene libraries and TRFLP analysis for reactor effluent samples.

\begin{tabular}{|c|c|c|c|c|c|c|c|}
\hline \multirow{2}{*}{$\begin{array}{l}\text { Reactor resp. } \\
\text { AD experiment }\end{array}$} & \multirow{2}{*}{ AD substrate ${ }^{a}$} & \multirow{2}{*}{$\begin{array}{l}\text { Day of sampling } \\
\text { (day) }\end{array}$} & \multirow{2}{*}{$\begin{array}{c}\text { Sample } \\
\text { denomination }\end{array}$} & \multicolumn{2}{|c|}{ Shannon diversity } & \multicolumn{2}{|c|}{ Richness resp. no. of TRFs } \\
\hline & & & & Bacteria & Archaea & Bacteria & Archaea \\
\hline Control & $100 \%$ CS (vol/volVS $\left.{ }^{b}\right)$ & 81 & CR-81 & 3.12 & 0.977 & 21 & 8 \\
\hline \multirow{2}{*}{$\begin{array}{l}\text { Experimental } \\
\text { phase } 1(\mathrm{EP} 1)\end{array}$} & \multirow{2}{*}{$\begin{array}{l}25 \% \mathrm{PM}+75 \% \mathrm{CS} \\
\text { (vol/vol VS) }\end{array}$} & 81 & ER-81 & 3.24 & 0.806 & 22 & 8 \\
\hline & & 162 & ER-162 & - & - & 20 & 6 \\
\hline \multirow{4}{*}{$\begin{array}{l}\text { Experimental } \\
\text { phase } 2(\mathrm{EP} 2)\end{array}$} & \multirow{4}{*}{$\begin{array}{l}50 \% \mathrm{PM}+50 \% \mathrm{CS} \\
\text { (vol/vol VS) }\end{array}$} & 199 & ER- 199 & - & - & 17 & 6 \\
\hline & & 250 & ER-250 & 2.87 & 0.223 & 13 & 7 \\
\hline & & 300 & ER-300 & - & - & 15 & 5 \\
\hline & & 340 & ER-340 & 3.10 & 0.532 & 13 & 6 \\
\hline Control & $100 \%$ CS (vol/volVS $\left.{ }^{b}\right)$ & 340 & CR-340 & 3.11 & 1.32 & 16 & 9 \\
\hline
\end{tabular}

${ }^{a} \mathrm{CS}$, cattle slurry; PM, poultry manure.

${ }^{\mathrm{b}} \mathrm{VS}$, volatile substances. 
Table 2. Relative distribution of the terminal restriction fragments (TRFs) detected for Bacteria as the relative abundance of particular TRFs divided on the sum of relative abundance of all TRFs in the sample ( 0 , light green; 1 to 4 , green; 5 to 9, yellow; 10 to 14 , orange; $\geq 15$, red).

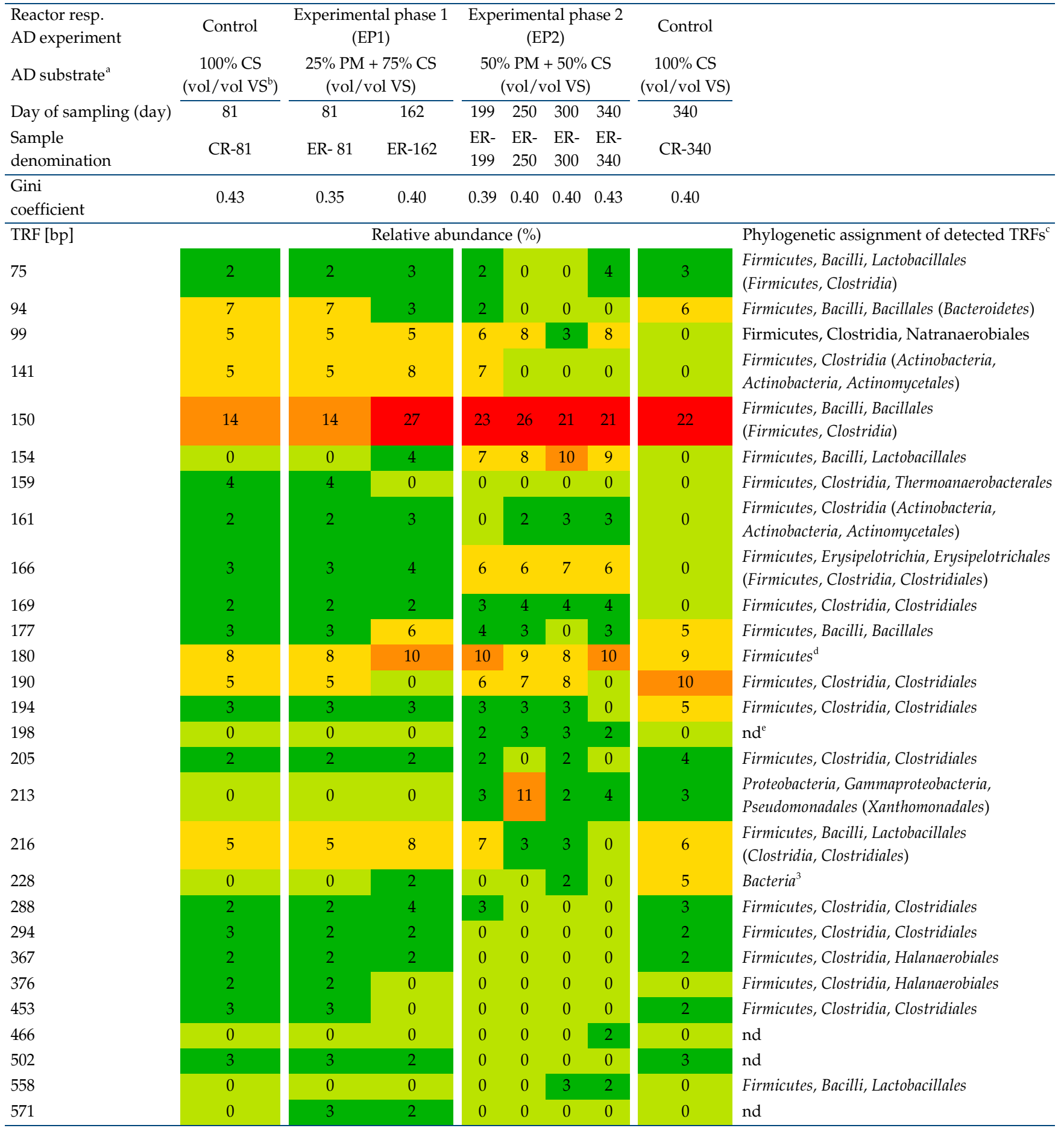

TRFs with relative abundance $>=2 \%$ were shown.

${ }^{\mathrm{a} C S}$, cattle slurry; PM, poultry manure.

${ }^{b} \mathrm{VS}$, volatile substances.

'In case of alternative sequencing or taxonomic identification results, corresponing taxonomic affiliation is given in brackets.

${ }^{\mathrm{d}}$ Lowest taxonomic rank.

end, not determined. 
indices were considerably higher for bacterial than for archaeal communities in both control and experimental reactors. Also the bacterial community organisation in all samples was more even than the archaeal one. At the same time, the Richness indices for both bacterial and archaeal communities were lower in thermophilic condition compared to mesophilic ones as was previously shown by Alsouleman et al. (Data not show) [20] and also was in accordance with [50], reporting that the thermophilic microbiome has lower diversity than the mesophilic one.

In the $C R$, the highest diversity was recorded for the bacterial and archaeal communities compared to the experimental reactor (Table 1). The bacterial community of the CR reactor at both sample points (CR-81 and CR-340) consisted mainly of members belonging to the phylum Firmicutes from orders Clostridiales, Bacillales, and Halanaerobiales (Table 2). The methanogenic community included members belonging to genera Methanosarcina, Methanobrevibacter, Methanothermobacter, and Methanoculleus (Table 3).

In the ER, during EP1, no significant changes were detected in the overall reactor performance. Interestingly, between sampling day 81 (sample ER-81) and 162 (sample

Table 3. Relative distribution of the terminal restriction fragments (TRFs) detected for Archaea as the relative abundance of particular TRFs divided on the sum of relative abundance of all TRFs in the sample (0, light green; 1 to 4 , green; 5 to 9 , yellow; 10 to 14 , orange; $\geq 15$, red).

\begin{tabular}{|c|c|c|c|c|c|c|c|c|}
\hline $\begin{array}{l}\text { Reactor resp. } \\
\text { AD experiment }\end{array}$ & Control & \multicolumn{2}{|c|}{$\begin{array}{c}\text { Experimental phase } 1 \\
\text { (EP1) }\end{array}$} & \multicolumn{4}{|c|}{$\begin{array}{c}\text { Experimental phase } 2 \\
\text { (EP2) }\end{array}$} & Control \\
\hline AD substrate ${ }^{a}$ & $\begin{array}{c}100 \% \text { CS } \\
(\text { vol/vol VS })^{b}\end{array}$ & \multicolumn{2}{|c|}{$\begin{array}{c}25 \% \mathrm{PM}+75 \% \mathrm{CS} \\
\text { (vol/vol VS) }\end{array}$} & \multicolumn{4}{|c|}{$\begin{array}{c}50 \% \mathrm{PM}+50 \% \mathrm{CS} \\
\text { (vol/vol VS) }\end{array}$} & $\begin{array}{c}100 \% \text { CS } \\
\text { (vol/vol VS) }\end{array}$ \\
\hline $\begin{array}{l}\text { Day of } \\
\text { sampling (day) }\end{array}$ & 81 & 81 & 162 & 199 & 250 & 300 & 340 & 340 \\
\hline $\begin{array}{l}\text { Sample } \\
\text { denomination }\end{array}$ & CR-81 & ER-81 & ER-162 & $\begin{array}{l}\text { ER- } \\
199\end{array}$ & $\begin{array}{l}\text { ER- } \\
250\end{array}$ & $\begin{array}{l}\text { ER- } \\
300\end{array}$ & $\begin{array}{l}\text { ER- } \\
340\end{array}$ & CR-340 \\
\hline $\begin{array}{l}\text { Gini } \\
\text { coefficient }\end{array}$ & 0.47 & 0.5 & 0.56 & 0.59 & 0.51 & 0.64 & 0.61 & 0.54 \\
\hline
\end{tabular}

\begin{tabular}{|c|c|c|c|c|c|c|c|c|c|}
\hline TRF [bp] & \multicolumn{8}{|c|}{ Relative abundance (\%) } & \multirow{2}{*}{$\begin{array}{l}\text { Phylogenetic assignment of detected TRFs } \\
\text { within phylum Euryarchaeota } \\
\mathrm{nd}^{\mathrm{c}}\end{array}$} \\
\hline 68 & 0 & 4 & 5 & 4 & 3 & 0 & 0 & 0 & \\
\hline 73 & 2 & 6 & 6 & 7 & 9 & 5 & 5 & 3 & $\begin{array}{l}\text { Methanomicrobia, Methanosarcinales, } \\
\text { Methanosarcinaceae, Methanosarcina }\end{array}$ \\
\hline 84 & 0 & 0 & 0 & 0 & 3 & 0 & 0 & 2 & $\begin{array}{l}\text { Methanomicrobia, Methanosarcinales, } \\
\text { Methanosarcinaceae, Methanosarcina }\end{array}$ \\
\hline 108 & 9 & 22 & 3 & 4 & 5 & 3 & 3 & 1 & $\begin{array}{l}\text { Methanomicrobia, Methanomicrobiales, } \\
\text { Methanomicrobiaceae, Methanoculleus }\end{array}$ \\
\hline 173 & 4 & 7 & 7 & 7 & 7 & 5 & 5 & 5 & nd \\
\hline 317 & 1 & 5 & 6 & 3 & 4 & 3 & 4 & 2 & $\begin{array}{l}\text { Methanobacteria, Methanobacteriales, } \\
\text { Methanobacteriaceae, Methanothermobacter }\end{array}$ \\
\hline 342 & 6 & 5 & 3 & 0 & 0 & 0 & 3 & 3 & $\begin{array}{l}\text { Methanobacteria, Methanobacteriales, } \\
\text { Methanobacteriaceae, Methanothermobacter }\end{array}$ \\
\hline 336 & 26 & 33 & 52 & 59 & 48 & 68 & 68 & 29 & $\begin{array}{l}\text { Methanobacteria, Methanobacteriales, } \\
\text { Methanobacteriaceae, Methanobrevibacter }\end{array}$ \\
\hline 471 & 3 & 0 & 0 & 0 & 0 & 0 & 0 & 3 & $\begin{array}{l}\text { Methanomicrobia, Methanosarcinales, } \\
\text { Methanosarcinaceae, Methanosarcina }\end{array}$ \\
\hline 627 & 28 & 4 & 0 & 0 & 0 & 0 & 0 & 29 & $\begin{array}{l}\text { Methanomicrobia, Methanosarcinales, } \\
\text { Methanosarcinaceae, Methanosarcina }\end{array}$ \\
\hline
\end{tabular}

TRFs with relative abundance $>=2 \%$ were shown.

${ }^{\mathrm{a}} \mathrm{CS}$, cattle slurry; PM, poultry manure.

${ }^{b} \mathrm{VS}$, volatile substances.

cnd, not determined. 

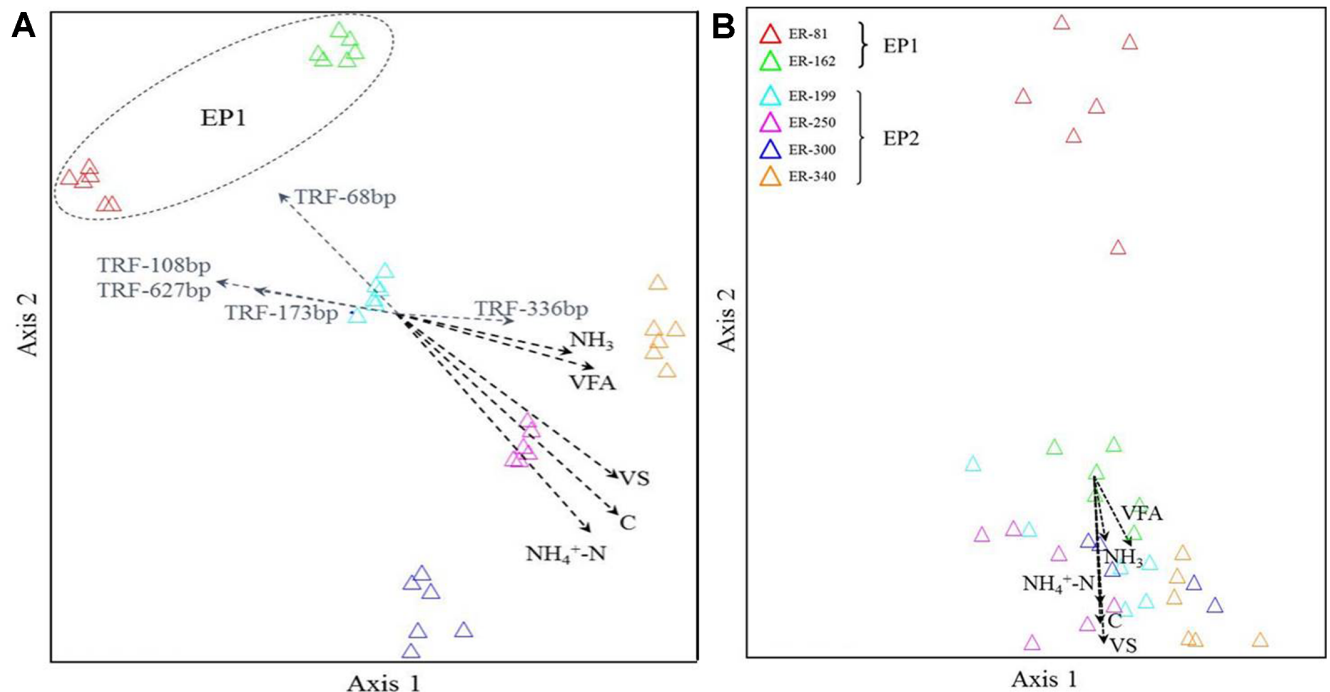

Fig. 2. Non-metric multidimensional scaling (NMS) of the effects of the prevalent process parameters in the experimental reactor (ER) in terms of ammonium nitrogen $\left(\mathrm{NH}_{4}{ }^{+}\right)$, free ammonia nitrogen $\left(\mathrm{NH}_{3}\right)$, total volatile fatty acids (VFA), volatile solids (VS) and conductivity $(\mathrm{C})$ on the bacterial and archaeal community structure.

The $x$-axis symbolizes the distance in ordinations space while the y-axis symbolizes the dissimilarity of the investigated objects. EP1, EP2 indicate exprimental phases. Sampling points are indicated by triangles. TRFs indicate detected methanogenic archaea.

ER-162), a definite shift in both the fermentative bacteria community and the methanogenic archaea community was observed (Fig. 2). The Gini coefficients of the bacterial community and the archaeal communities of ER-81 were 0.35 resp. 0.50, and for ER-162 were 0.40 resp. 0.56 which indicate a well-balanced community composition at both process stages as they were in the medium range of the community organisation.

Similar to the CR, in the ER the most abundant members of the bacterial community were also belonged to the order Clostridiales followed by members of the order Bacillales (Table 2). This result was supported by the performed indicator species analysis where the highest significant indicator values $(\mathrm{IV}=100 ; p \leq 0.05)$ in this phase were found for the TRFs related to the order Clostridiales independent from the tested process factors (data not shown). The calculated pairwise distance between the bacterial communities of CR-81 and ER-81 resp. ER-162 showed a change in the bacterial community composition in the ER of up to $17 \%$ (Table 4 ).

In the ER, the archaeal community during the EP1 showed more distinct changes in their composition as the relative abundance of members belonging to the genus Methanobrevibacterreached increased to $52 \%$ of the entire archaeal community in the ER-162 comparing by $26 \%$ in control reactor (Table 3). This increase through the whole experimental phase was accompanied with a apparent decrease in the relative abundance of members belonging to the family Methanosarcinaceae TRF-627. While other members of this genus did not affect (e.g., TRF-73) similar to members of genus Methanothermobacter (TRF-317). The calculated pairwise distance between the archaeal communities of CR-81 and ER-81 resp. ER-162 showed a change in the archaeal community composition in the ER of up to $32 \%$ (Table 5).In the ER and during the EP2 (which was divided into three phases depending on the reactor performance (Fig. 1), Shannon's diversity index for the bacterial community of the sample ER-250 reflected the lowest diversity of the microbial community during the entire experimental phase (Table 1).

A slight alteration in the structure of the bacterial community in sample ER-199, the first disturbance phases (Fig. 1), was detected (Table 2). This slight alteration was also supported by the calculated pairwise distance between the bacterial communities of ER-162 and ER-199, which reached up to $9 \%$ (Table 4 ).

For members of class Euryarchaeota, a clear decrease in the relative abundance of the genus Methanothermobacter accompanied with a continuous increase in the relative abundance of the genus Methanobrevibacter was detected (Table 3).

Between day 250 and day 300 (Fig. 1, second phase 
Table 4. Similarity matrix in comparison of the bacterial communities.

\begin{tabular}{|c|c|c|c|c|c|c|c|c|}
\hline Reactor resp. AD experiment & Control & Experime & se 1 (EP1) & & erimenta & hase $2(\mathrm{E}$ & & Control \\
\hline AD substrate ${ }^{a}$ & $\begin{array}{c}100 \% \text { CS } \\
\left(\mathrm{vol} / \mathrm{vol} \mathrm{VS}^{\mathrm{b}}\right)\end{array}$ & $\begin{array}{r}25 \% \\
(\mathrm{v}\end{array}$ & $\begin{array}{l}\% \text { CS } \\
\text { S) }\end{array}$ & & $\begin{array}{r}50 \% \mathrm{PM} \\
\quad(\mathrm{vol} /\end{array}$ & $\begin{array}{l}50 \% \text { CS } \\
1 \text { VS) }\end{array}$ & & $\begin{array}{c}100 \% \text { CS } \\
\text { (vol/vol VS) }\end{array}$ \\
\hline Day of sampling (day) & 81 & 81 & 162 & 199 & 250 & 300 & 340 & 340 \\
\hline Sample & CR-81 & ER-81 & ER-162 & ER-199 & ER-250 & ER-300 & ER-340 & CR-340 \\
\hline CR-81 & 100 & 99 & 83 & 81 & 65 & 62 & 60 & 81 \\
\hline ER-81 & & 100 & 84 & 81 & 65 & 62 & 60 & 81 \\
\hline ER-162 & & & 100 & 91 & 77 & 75 & 80 & 78 \\
\hline ER-199 & & & & 100 & 89 & 88 & 84 & 79 \\
\hline ER-250 & & & & & 100 & 91 & 91 & 71 \\
\hline ER-300 & & & & & & 100 & 86 & 71 \\
\hline ER-340 & & & & & & & 100 & 57 \\
\hline CR-340 & & & & & & & & 100 \\
\hline
\end{tabular}

The calculated pairwise similarity considered both, changes in the number and the relative abundance of each detected terminal restriction fragment within and between two samples depending on Pearson algorithm.

${ }^{\mathrm{a}} \mathrm{CS}$, cattle slurry; PM, poultry manure.

${ }^{\mathrm{b}} \mathrm{VS}$, volatile substances.

showing short-termed stable biogas yield), the calculated pairwise distance between the bacterial communities of ER-250 and ER-300 showed a change in the bacterial community composition of up to $9 \%$ (Table 4 ).

Regarding the archaeal community, an increase in the relative abundance of the genus Methanobrevibacter was recorded which formed $68 \%$ of the entire archaeal community structure, whereby members belonging to the genus Methanosarcina completely disappeared (Table 3).
At the end of the fermentation experiment, in sample ER340 , the most abundant members of the bacterial community were also belonged to the phylum Firmicutes mainly from the orders Bacillales, followed by members of the order Lactobacillales and Clostridiales (Table 2).

In the course of the experiment, the trend of the archaeal community organization moved in the same way as ER199 , and the most abundant members were belonged to the genus Methanobrevibacter, whereby members belonging to

Table 5. Similarity matrix in comparison of the archaeal communities.

\begin{tabular}{|c|c|c|c|c|c|c|c|c|}
\hline Reactor resp. AD experiment & Control & Experim & se 1 (EP1) & & erimenta & hase $2(\mathrm{E}$ & & Control \\
\hline AD substrate ${ }^{a}$ & $\begin{array}{c}100 \% \text { CS } \\
\left(\mathrm{vol} / \mathrm{vol} \mathrm{VS}^{\mathrm{b}}\right)\end{array}$ & $25 \%$ & $\begin{array}{l}\% \text { CS } \\
\text { S) }\end{array}$ & & $\begin{array}{r}50 \% \mathrm{PM} \\
\quad(\mathrm{vol} /\end{array}$ & $\begin{array}{l}50 \% \text { CS } \\
1 \text { VS) }\end{array}$ & & $\begin{array}{c}100 \% \text { CS } \\
\text { (vol/vol VS) }\end{array}$ \\
\hline Day of sampling (day) & 81 & 81 & 162 & 199 & 250 & 300 & 340 & 340 \\
\hline Sample & CR-81 & ER-81 & ER-162 & ER-199 & ER-250 & ER-300 & ER-340 & CR-340 \\
\hline CR-81 & 100 & 93 & 68 & 63 & 65 & 61 & 60 & 90 \\
\hline ER-81 & & 100 & 66 & 77 & 67 & 65 & 63 & 79 \\
\hline ER-162 & & & 100 & 79 & 83 & 82 & 80 & 72 \\
\hline ER-199 & & & & 100 & 86 & 85 & 84 & 70 \\
\hline ER-250 & & & & & 100 & 88 & 86 & 56 \\
\hline ER-300 & & & & & & 100 & 90 & 53 \\
\hline ER-340 & & & & & & & 100 & 52 \\
\hline CR-340 & & & & & & & & 100 \\
\hline
\end{tabular}

The calculated pairwise similarity considered both, changes in the number and the relative abundance of each detected terminal restriction fragment within and between two samples depending on Pearson algorithm.

${ }^{a} \mathrm{CS}$, cattle slurry; PM, poultry manure.

${ }^{\mathrm{b}} \mathrm{VS}$, volatile substances. 
the genus Methanosarcina completely disappeared (Table 3). After this inhibited steady state phase, a severe perturbation in the process performance was recorded.

\section{Discussion}

In the $C R, A D$ was performed by members of the bacterial phylum Firmicutes in combination with obligate or facultative hydrogenotrophic methanogens, namely of genera Methanosarcina, Methanobrevibacter, Methanothermobacter, and Methanoculleus. The predominance of the Firmicutes phylum is mostly explained by its capability to produce diverse enzymes performing celluloylsis, hydrolysis, acidogenesis, and acetogenesis. This microbial structure under thermophilic conditions was in accordance with previously published results and supported the assumption of more or less stable microbial biocenoses and metabolic activity in the CR [11, 23, 51-53]. The moderate alteration in the microbial community structure in the $C R$ between sampling days 81 and 340 with constant biogas yields can be assumed to be more related to the natural development of the microbial community itself (Table 4)

In the ER, during EP1, no significant effects on the reactor performance were recorded. The TAN reached a maximum of $3 \mathrm{~g} / \mathrm{kg}_{\mathrm{FM}}$ with a corresponding $\mathrm{NH}_{3}$ content of $0.4 \mathrm{~g} / \mathrm{kg}_{\mathrm{FM}}$, values which are lower than the published thresholds for process inhibition [11, 14, 54]. Even a slight increase in the VFA concentrations was recorded in this experimental phase, the degradation process run stably. It is assumed that the increase in the TAN concentration led to an increase in the buffer capacity, which supports a stable process. The recorded VFAs concentrations were lower than the recorded inhibition thresholds $[55,56]$.

Nevertheless, it is known that the used feedstock can affect the microbial community structure [57-60]. Hence, in this study, a definite shift in the microbiome structure was observed between ER-81 and ER-162 in the EP1, according to $25 \%$ PM addition as well as the consequent abiotic parameters. In the first sample ER-81 of the EP1 a minor change in the microbial community structure was recorded as was indicated by the changes of the relative abundance of the detected archaeal and bacterial TRFs. While in the second sample ER-162 of EP1, a clear shift was detected as indicated by the similarity values (Tables 4 and $5)$, the relative abundance of the detected archaeal and bacterial TRFs (Tables 2 and 3) in addition to the NMS analysis. The NMS revealed no significant correlation between the investigated process parameters and the related arrangement of the bacterial community in the EP1.
So that the bacterial community of EP1 (ER-81 and ER-162) formed a separate cluster (Fig. 2), while the archaeal community structure already showed a clear shift during EP1 as the archaeal community of the first sample of EP1 (ER-81) formed a separate cluster (Fig. 2).

It can be assumed that functional redundancy was the primary microbial strategy in EP1, ensuring an ongoing and stable biogas production as the compositional shifts did not affect significantly the reactor performance [61, 62]. The results of this study showed that the phylum Firmicutes was the most abundant phylum during the whole experimental phase which was shown previously $[63,64]$

The archaeal community in EP1 seemed to have lower tolerance values for the elevated TAN. The more sensitive response of the archaeal community was related to a clear decrease in the abundance of some obligate (Methanoculleus) or facultative (Methanosarcina) hydrogenotrophic methanogens which accompanied with a substantial increase in the abundance of other and exclusively hydrogenotrophic genus Methanobrevibacter (Table 2). These results are in accordance with $[22,50]$ reporting that the obligate or facultative acetoclastic methanogens dominate the archaeal community preferentially at medium TAN, VFA, and/or salt concentrations. High concentrations of these parameters in combination with thermophilic conditions were positively correlated with a predominance of obligate hydrogenotrophic methanogens.

Hydrogenotrophic methanogens utilize carbon dioxide $\left(\mathrm{CO}_{2}\right)$ and molecular hydrogen $\left(\mathrm{H}_{2}\right)$ for methane production. Thus, the acetate produced by fermentative bacteria has to be converted via the acetate oxidation pathway performed by syntrophic bacteria $[65,66]$. This fact could explain the previous slight recorded changes within the bacterial community composition of the EP1. To conclude, the shift within the microbial community was the result of a synergetic effect of physical (temperature) and chemical (partial feedstock change) factors which had no effects on the overall process performance.

In the second experimental phase (EP2; day 177- 341) the amount of PM was doubled to 50\% (vol/vol based on VS). As expected, shortly after starting EP2, the reactor performance was distinctly negatively influenced symbolized by a decrease in both the biogas yield and the methane content which was significantly related to a gradual increase in the $\mathrm{NH}_{4}{ }^{+}-\mathrm{N}$ and $\mathrm{NH}_{3}$ as well as the VFA concentrations (Fig. 1).

The high VFA and TAN concentrations led to the presence of them in their un-dissociated forms, which are more toxic for microorganisms $[67,68]$. 
As is known, in a highly buffered system like this system, the VFA is the best indicator for indicating process imbalance and reactor failure [69]). The relative alteration of the VFA concentration in EP2 reached to $36 \mathrm{~g} / 1$ compared with $1.13 \mathrm{~g} / 1$ in the control reactor.
During EP2, a three-stage process disturbance was recorded: an initial disturbance (as mentioned above), a short-termed stable biogas yield stage, and a final complete process disturbance resulting in complete process failure. The initial accumulation in a VFA led to a drop in the $\mathrm{pH}$

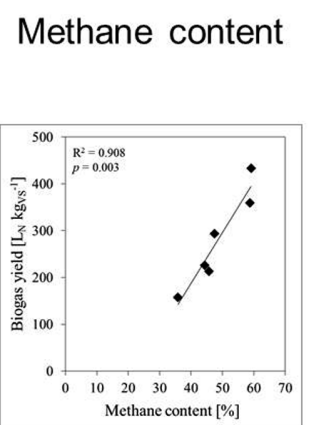

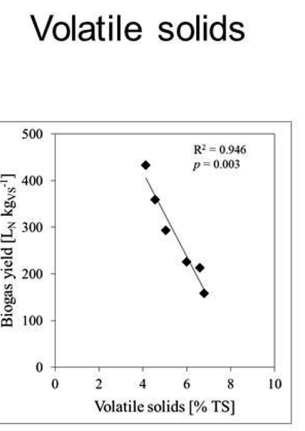

\section{Volatile fatty acids}
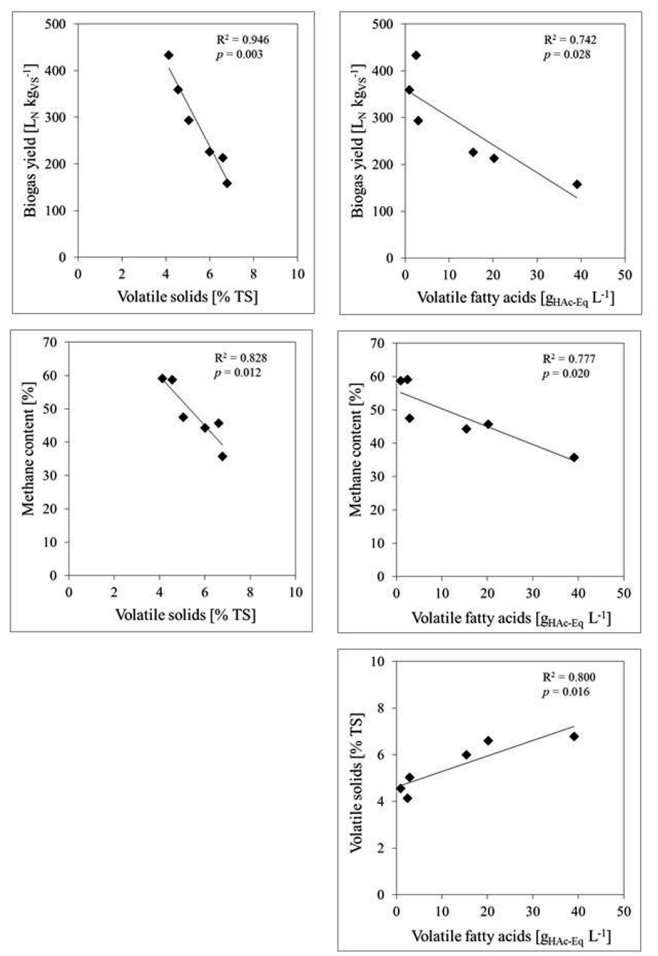

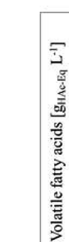
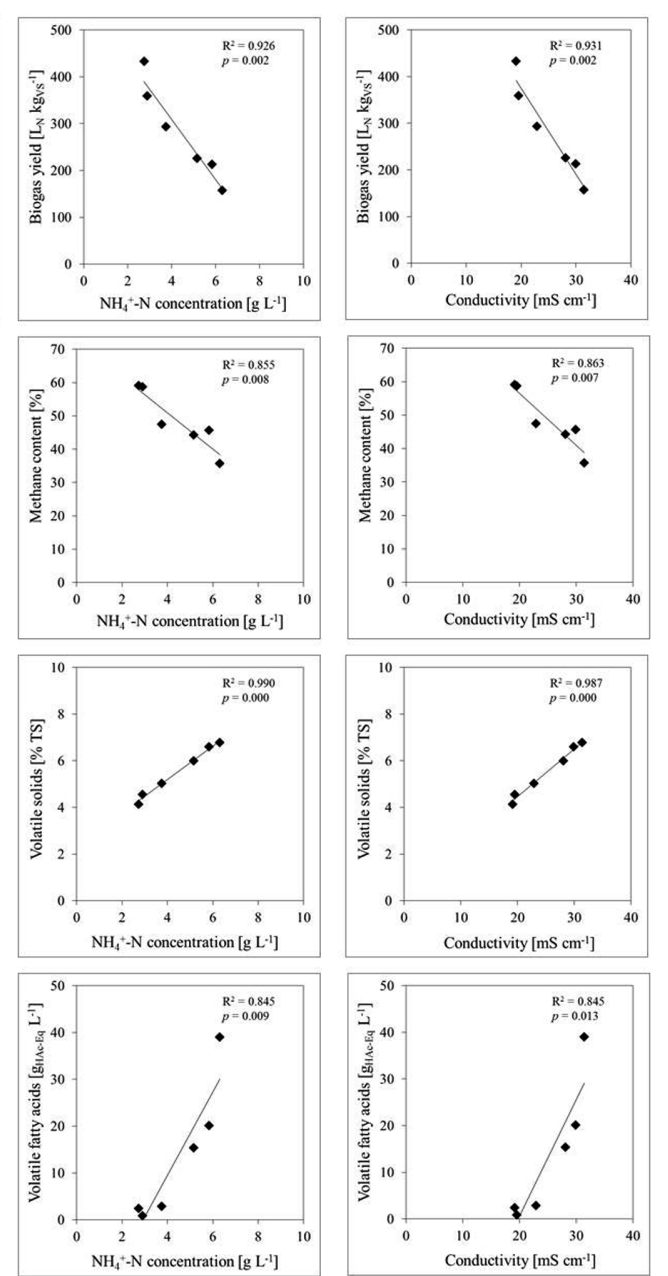

Conductivity (salt content)

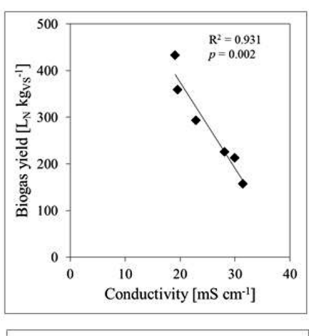

0.
0.
0
0
0
0
$\frac{1}{2}$
$\frac{\Phi}{2}$

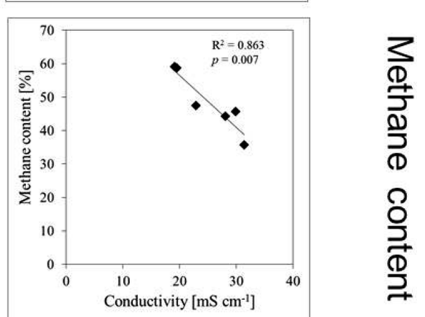

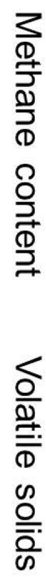

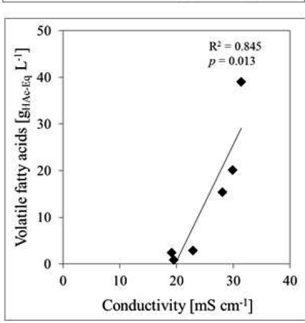

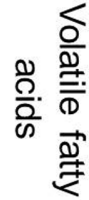

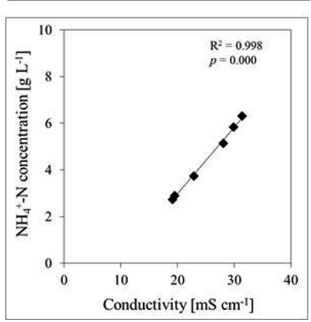

Fig. 3. Correlation matrix indicated by linear regression among and between the operational parameters.

The operational parameter values were determined for 6 sampling points of the experimental reactor. Statistical significance was established at the $p<0.05$ level. 
value and hence, a decrease in the $\mathrm{NH}_{3}$ content (between day 250 and 270, Fig. 1). It can be assumed that these conditions encouraged the microbial communities especially the archaeal community to adapt and recover again which could be interpreted the subsequent process stability at elevated TAN but with a lower biogas yield and methane content [14].

The reason for the final reactor performance deterioration could not be related to one, but rather to different prevalent environmental factors (Fig. 3).This is reflected in the NMS analyses results which showed that the variation within the bacterial and the archaeal community structure community in EP2 could be related to different parameters; $\mathrm{VFA}, \mathrm{NH}_{4}{ }^{+} \mathrm{N}$, $\mathrm{NH}_{3}$, salt content, and/or VS (Fig. 2). The salt content was symbolized in our study by the conductivity which reached to the reported threshold value of $30 \mathrm{mS} / \mathrm{cm}$ [57, 70]. Here, it could be assumed depending on our finding that, the alteration in the microbial community structure in the ER was more related to the strong impact of the PM addition (Table 4). As the methanogenic activity is seriously inhibited, it can be assumed that the growth of acid converting bacteria is restricted as they can only grow if the $\mathrm{H}_{2}$ is consumed by their syntrophic archaeal partners which subsequently led to a VFA accumulation of more than $38 \mathrm{~g} / \mathrm{l}$ at the end of this experimental phase. Based on these findings and in comparison with an $\mathrm{AD}$ experiment performed under the same but mesophilic conditions [20], an anaerobic microbiome adapted to thermophilic conditions can be assumed as much more sensitive for process disturbances in consequence of biomass load with high contents of organic nitrogen.

\section{Acknowledgments}

This study was supported by the Erasmus Mundus Joseleen Programm provided by the European Commission (grant number FIIR 2010/34) as well as by the Leibniz Institute for Agricultural Engineering and Bioeconomy Potsdam-Bornim. I would like to thank Prof. Bernd Linke for his support in developing this project. I would like also to thank Dr. Michael Klocke for his valuable participation in the discussions of results and data interpretation. Kerstin Mundt and Carsten Jost are thanked for their excellent technical support.

\section{Conflict of Interest}

The authors have no financial conflicts of interest to declare.

\section{References}

1. Barret M, Gagnon N, Morissette B, Kalmokoff ML, Topp E, Brooks SPJ, et al. 2015. Phylogenetic identification of methanogens assimilating acetate-derived carbon in dairy and swine manures. Syst. Appl. Microbiol. 38: 56-66.

2. Börjesson P, Berglund M. 2007. Environmental systems analysis of biogas systems - Part II: Environmental impact of replacing various reference systems. Biomass Bioenergy 31: 326-344.

3. Arthurson V. 2009. Closing the global energy and nutrient cycles through application of biogas residues to agricultural land - potential benefits and drawbacks. Energies 2: 226-242.

4. Abbassi-Guendouz A, Brockmann D, Trably E, Dumas C, Delgenès JP, Steyer JP, et al. 2012. Total solids content drives high solid anaerobic digestion via mass transfer limitation. Bioresour. Technol. 111: 55-61.

5. Ahring BK. 1993. Perspectives for anaerobic digestion. Adv. Biochem. Eng. Biotechnol. 81: 1-30.

6. Shi J, Wang Z, Stiverson JA, Yu Z, Li Y. 2013. Reactor performance and microbial community dynamics during solid-state anaerobic digestion of corn stover at mesophilic and thermophilic conditions. Bioresour. Technol. 136: 574-581.

7. Wilson CA, Murthy SM, Fang Y, Novak JT. 2008. The effect of temperature on the performance and stability of thermophilic anaerobic digestion. Water Sci. Technol. 57: 297-304.

8. Akyol Ç, Turker G, Ince O, Ertekin E, Üstünerc O, Incea B. 2016. Performance and microbial community variations in thermophilic anaerobic digesters treating OTC medicated cow manure under different operational conditions. Bioresour. Technol. 205: 191-198.

9. Guo X, Wang C, Sun F, Zhu W, Wu W. 2014. A comparison of microbial characteristics between the thermophilic and mesophilic anaerobic digesters exposed to elevated food waste loadings. Bioresour. Technol. 152: 420-428.

10. Hori T, Haruta S, Sasaki D, Hanajima D, Ueno Y, Ogata A, et al. 2015. Reorganization of the bacterial and archaeal populations associated with organic loading conditions in a thermophilic anaerobic digester. J. Biosci. Bioeng. 19: 337-344.

11. Niu QG, Qiao W, Qiang H, Li YY. 2013. Microbial community shifts and biogas conversion computation during steady, inhibited and recovered stages of thermophilic methane fermentation on chicken manure with a wide variation of ammonia. Bioresour. Technol. 146: 223-233.

12. Hashimoto AG. 1986. Ammonia inhibition of methanogenesis from cattle wastes. Agricultural Wastes. 17: 241-261.

13. Koster IW, Lettinga G. 1988. Anaerobic digestion at extreme ammonia concentrations. Biological Wastes. 25:51-59.

14. Angelidaki I, Ahring BK. 1993. Thermophilic anaerobic digestion of livestock waste: the effect of ammonia. Appl. Biochem. Biotechnol. 38: 560-564.

15. Poggi-Varaldo HM, Rodriguez-Vazquez R, FernandezVillagomez G, Esparza-Garcia F. 1997. Inhibition of mesophilic 
solid substrate anaerobic digestion by ammonia nitrogen. Appl. Microbiol. Biotechnol. 47: 284-291.

16. Gallert C, Winter J. 1997. Mesophilic and thermophilic anaerobic digestion of source-sorted organic wastes: effect of ammonia on glucose degradation and methane production. Appl. Microbiol. Biotechnol. 48: 405-410.

17. Hansen KH, Angelidaki I, Ahring BK.1998. Anaerobic digestion of swine manure: inhibition by ammonia. Water Res. 32: 5-12.

18. Sung S, Liu T. 2003. Ammonia inhibition on thermophilic anaerobic digestion. Chemosphere 53: 43-52.

19. Nakakubo R, Moller HB, Nielsen AM, Matsuda J. 2008. Ammonia inhibition ofmethanogenesis and identification of process indicators during anaerobic digestion. Environ. Eng. Sci. 25: 1487-1496.

20. Alsouleman K, Linke B, Klang J, Klocke M, Krakat N, Theuerl S. 2016. Reorganisation of a mesophilic biogas microbiome as response to a stepwise increase of ammonium nitrogen induced by poultry manure supply. Bioresour. Technol. 208: 200-204.

21. Hao L, Lü F, Mazéas L, Quémnér ED, Madigou C, Guenne A, et al. 2015. Stable isotope probing of acetate fed anaerobic batch incubations shows a partial resistance of acetoclastic methanogenesis catalyzed by Methanosarcina to sudden increase of ammonia level. Water Res. 69: 90-99.

22. Fotidis I, Karakashev D, Angelidaki I. 2014. The dominant acetate degradation pathway/methanogenic composition in full-scale anaerobic digesters operating under different ammonia levels. Int. J. Environ. SciTe. 11: 2087-2094.

23. Rademacher A, Nolte C, Schönberg M, Klocke M. 2012. Temperature increases from 55 to $75^{\circ} \mathrm{C}$ in a two-phase biogas reactor result in fundamental alterations within the bacterial andarchaeal community structure. Appl. Microbiol. Biotechnol. 96: 565-576.

24. Yabu H, Sakai C, Fujiwara T, Nishio N, Nakashimada Y. 2011. Thermophilic two-stage dryanaerobic digestion of model garbage with ammonia stripping. J. Biosci. Bioeng. 111: 312319.

25. Weiss A, Jérôme V, Freitag R, Mayer HK. 2008. Diversity of the resident microbiota in a thermophilic municipal biogas plant. Appl. Microbiol. Biotechnol. 81: 163-173 .

26. Niu Q, Kubota K, Qiao W, Jing Z, Zhang Y, Yu-You L. 2014. Effect of ammonia inhibition on microbial community dynamic and process functional resilience in mesophilic methane fermentation of chicken manure. J. Chem. Technol. Biotechnol. 90: 2161-2169.

27. Yenigün O, Demirel B. 2013. Ammonia inhibition in anaerobic digestion: a review. Process Biochem. 48: 901-911.

28. Hill R, Saetnan ER, Scullion J, Gwynn-Jones D, Ostle N, Edwardset A.2016. Temporal and spatial influences incur reconfiguration of Arctic heathland soil bacterial community structure. Environ. Microbiol. 18: 1942-1953.
29. Ji Y, Angel R, Klose M, Claus P, Marotta H, Pinho L, et al. 2016. Structure and function of methanogenicmicrobial communities in sediments of Amazonian lakes with different water types. Environ. Microbiol. 18: 5082-5100.

30. Van Goethem MW, Makhalanyane TP, Valverde A, Cary SC, Cowan DA. 2016. Characterization of bacterial communities in lithobionts and soil niches from Victoria Valley, Antarctica. FEMS Microbiol. Ecol. 92: fiw051.

31. Weise L, Ulrich A, Moreano M, Gessler A, Kayler ZE, Steger K, et al. 2016. Water level changesaffect carbon turnover and microbial community composition in lake sediments. FEMS Microbiol. Ecol. 92: fiw035.

32. Cabezas A, de Araujo JC, Callejas C, Gales, A. Hamelin J, Marone A, et al. 2015. How to use molecular biology tools for the study of the anaerobic digestion process? Rev. Environ. Sci. Bio-Technol. 14: 555-593.

33. Van Dorst J, Bissett A, Palmer AS, Brown M, Snape I, Stark JS, et al. 2014. Community fingerprinting in a sequencing world. FEMS Microbiol. Ecol. 89: 316-330.

34. Sboner A, Mu XJ, Greenbaum D, Auerbach RK, Gerstein MB. 2011. The real cost of sequencing: higher than you think! Genome Biol. 12(8): 125.

35. TalbotG, Topp E, Palin MF, Massé DI. 2008. Evaluation of molecular methods used for establishing the interactions and functions of microorganisms in anaerobic bioreactors. Water Res. 42: 513-537.

36. De Vrieze J, Ijaz UZ, Saunders AM, Theuerl S. 2018. Terminal restriction fragment length polymorphism is an "old school" reliable technique for swift microbial community screening in anaerobic digestion. Sci. Rep. 8: 16818.

37. Bühligen F, Lucas R, Nikolausz M, Kleinsteuber SA.2016. T-RFLP database for the rapid profiling of methanogenic communities in anaerobic digesters. Anaerobe. 39: 114-116.

38. Prakash O, Pandey PK, Kulkarni GJ, Mahale KN, Shouche YS. 2014. Technicalities and glitches of terminal restriction fragment length polymorphism (T-RFLP). Indian J. Microbiol. 54: 255-261.

39. Weissbrodt DG, Shani N, Sinclair L, Lefebvre G,Rossi P, Maillard J, et al. 2012. PyroTRF-ID: a novel bioinformatics methodology for the affiliation of terminalrestriction fragments using 16S rRNA gene pyrosequencing data. BMC Microbiol. 12: 1306.

40. VDI. 2006. Fermentation of organic materials - Characterisation of the substrate, sampling, collection of material data, fermentation tests. Verein Deutscher Ingenieure.

41. Schattauer A, Abdoun E, Weiland P, Plöchl M, Heiermann M. 2011. Abundance of trace elements in demonstration biogas plants. Biosyst. Eng. 108: 57-65.

42. Schönberg M, Linke B. 2012. The influence of the temperature regime on the formation of methane in a twophase anaerobic digestion process. Eng. Life Sci. 12: 279-286.

43. Klang J, Theuerl S, Szewzyk U, Huth M, Tölle R, Klocke M. 2015. Dynamic variation of the microbial community structure 
during the long- time mono- fermentation of maize and sugar beet silage. Microb. Biotechnol. 8: 764-775.

44. Dufrêne M, Legendre P. 1997. Species assemblages and indicator species: the need for a flexible asymmetrical approach. Ecol. Monogr. 67: 345-366.

45. McCune B, Mefford MJ. 2011. PC-ORD. Multivariate analysis of ecological data. Version 6.08, Gleneden Beach, Oregon, U.S.A.

46. Clarke KR.1993. Non-parametric multivariate analyses of changes in community structure. Australian J. Ecol. 18: 117143.

47. Theuerl S, Kohrs F, Benndorf D, Maus I, Wibberg D, Schlüter A, et al. 2015. Community shifts in a well-operating agricultural biogas plant: how process variations are handled by the microbiome, Appl. Microbiol. Biotechnol. 99: 7791-7803.

48. Carballa M, Smits M, Etchebehere C, Boon N, Verstraete W. 2011. Correlations between molecular and operational parameters in continuous lab-scale anaerobic reactors. Appl. Microbiol. Biotechnol. 89: 303-314.

49. Verstraete W, Wittebolle L, Heylen K, Vanparys B, de Vos P, van de Wiele $T$, et al. 2007. Microbial resource management: the road to go for environmental biotechnology. Eng. Life Sci. 7: 117-126.

50. Niu Q, Takemura Y, Kubota K, Li Y Y. 2015 .Comparing mesophilic and thermophilic anaerobic digestion of chicken manure: microbial community dynamics and process resilience. Waste Manag. 43: 114-122.

51. De Vrieze J, Saunders AM, He Y, Fang J, Nielsen PH, Verstraete $\mathrm{W}$, et al. 2015. Ammonia and temperature determine potential clustering in the anaerobic digestion microbiome. Water Res. 75: 312-323.

52. Campanaro S, Treu L, Kougias PG, de Francisci D, Valle G, Angelidaki I. 2016. Metagenomic analysis and functional characterization of the biogas microbiome using high throughput shotgun sequencing and a novel binning strategy. Biotechnol. Biofuels. 9: 26.

53. Pap B, Györkei Á, Boboescu IZ, Nagy IK, Bíró T, Kondorosi É, et al. 2015. Temperaturedependent transformation of biogasproducing microbial communities points to the increased importance of hydrogenotrophic methanogenesis under thermophilic operation. Bioresour. Technol. 177: 375-380.

54. Lv Z, Hu M, Harms H, Richnow HH, Liebetrau J, Nikolausz M. 2014. Stable isotope composition of biogas allows early warning of complete process failure as a result of ammonia inhibition in anaerobic digesters. Bioresour. Technol. 167: 251259.

55. Wang Y, Zhang Y, Wang J, Meng L. 2009. Effects of volatile fatty acid concentrations on methane yield and methanogenic bacteria. Biomass Bioenergy 33: 848-853.
56. Drosg, B. 2013. Process monitoring in biogas plants. In: IEA Bioenergy Task 37 - Energy from Biogas.

57. De Vrieze J, Christiaens MER, Walraedt D, Devooght A, Ijaz UZ, Boon N. 2017. Microbial community redundancy in anaerobic digestion drives process recovery after salinity exposure. Water Res. 111: 109-117.

58. Lu X, Rao S, Shen Z, Lee PKH. 2013. Substrate induced emergence of different active bacterial and archaeal assemblages during biomethane production. Bioresour. Technol. 148: 517-524.

59. Zhang W, Werner JJ, Agler MT, Angenent LT. 2014. Substrate type drives variation in reactor microbiomes of anaerobic digesters. Bioresour. Technol. 151: 397-401.

60. Ziganshina1 EE, Belostotskiy DE, Shushlyaev RV, Miluykov VA, Vankov PY, Ziganshin AM. 2014. Microbial community diversity in anaerobic reactors digesting turkey, chicken, and swine wastes. J. Microbiol. Biotechnol. 24: 1464-1472.

61. Louca S, Polz MF, Mazel F, Albright MBN, Huber JA, O'Connor MI, et al. 2018. Function and functional redundancy in microbial systems. Nat. Ecol. Evol. 2:936-943.

62. Allison SD, Martiny JB. 2008. Resistance, resilience, and redundancy in microbial communities. Proc. Natl. Acad. Sci. USA 105: 11512-11519.

63. Kovács E, Wirth R, Maróti G, Bagi Z, Rákhely G, Kovács KL. 2013. Biogas production from protein-rich biomass: fedbatch anaerobic fermentation of casein and of pig blood and associated changes in microbial community composition, PLoS One 8: e77265.

64. Kovács E, Wirth R, Maróti G, Bagi Z, Nagy K, Minárovits J, et al. 2015. Augmented biogas production from protein-rich substrates and associated metagenomic changes. Bioresour. Technol. 178: 254-261.

65. Westerholm M, Moestedt J, Schnürer A. 2016. Biogas production through syntrophic acetate oxidation and deliberate operating strategies for improved digester performance. Appl. Energy 179: 124-135.

66. Dolfing J. 2014. Thermodynamic constrains of SAO. Appl. Environ. Microbiol. 80: 1539-1541.

67. Amani T, Nosrati M, Sreekrishnan T R. 2010. Anaerobic digestion from the viewpoint of microbiological, chemical, and operational aspects - a review. Environ. Rev. 18: 255-278.

68. Whittle IHF, Walter A, Ebner C, Insam H. 2014. Investigation into the effect of high concentrations of volatile fatty acids in anaerobic digestion on methanogenic communities. Waste Manag. 34: 2080-2089.

69. Murto M, Björnsson L, Mattiasson B. 2004. Impact of food industrial waste on anaerobic co-digestion of sewage sludge and pig manure. J. Environ. Manage. 70: 101-107.

70. Chen Y, Cheng JJ, Creamer KS. 2008. Inhibition of anaerobic digestion process: a review. Bioresour. Technol. 99: 4044-4064. 